\title{
Training Mode of Professional Talents in Comprehensive Colleges and Universities in the Context of Sports Training
}

\author{
Wenchao Li \\ Capital University of Physical Education and Sports, Beijing, 100191
}

Keywords: Sports training, comprehensive colleges and universities, professional talent training

\begin{abstract}
This paper mainly introduces how to train professional talents in the context of sports training in detail, firstly proposes the meaning of professional talent training in comprehensive colleges and universities, then analyzes the professional ability of graduates from sports training major in China in detail, finally summarizes how to better train professional talents of sports training major in comprehensive colleges and universities of China, and puts forward specific schemes thereof.
\end{abstract}

\section{Introduction}

Sports training major has attracted great attention of many sports schools, has also achieved great development, but how to remain strengthening understanding of sports training in professional talent training of comprehensive colleges and universities seems to far exceed expectations. This paper introduces the sports training major mainly from the perspective of attaching enhanced importance to this major by comprehensive colleges and universities, so as to still further promote the development of sports undertakings in the future curriculum development, especially enhance the competitiveness of comprehensive colleges and universities and specialized sports colleges and universities in this aspect.

\section{Significance of talent training of sports training major in comprehensive colleges and universities}

After the economic development level is improved, people pay more attention to improving their personal physical quality. With the development of the global sports undertakings, more attention is paid to quality cultivation of sports training talents, rather than quantity. Therefore, it is necessary to keep up with the pace of the times, and make corresponding changes, where one of the most important links is reform from the perspective of education. Sports training is one of the important major majors in institutions of higher learning in China. How to train sports training talents in comprehensive colleges and universities is the most important issue. Due to the importance of sports training for sports talent training, paying attention to the arrangement of related curricula and the overall plan of training objectives is the most important for comprehensive colleges and universities to train professional talents. Attaching strengthened importance to sports training major will play a good role in improving the overall level of comprehensive colleges and universities, particularly achievements in the aspect of sports.

Over the years, there is no lack of sports training in any specific field related to specialized sports colleges and universities, which is also an important reason why their sports achievements are so satisfactory. Just as the names imply, comprehensive colleges and universities pay attention to the development of a variety of specialized modes, and are very difficult to concentrate all manpower, material resources and financial resources to the development of sports training, compared with the traditional sports colleges and universities. Therefore, professional talent training seems to be more difficult. Strengthening understanding of sports training, and strengthening scientific and reasonable course setting related to basic training courses thereof will be bound to push the pace of specialized talent training in comprehensive colleges and universities. 


\section{Analysis on the current situation of professional ability of graduates from sports training major}

Referees play an important role in sports competitions. Therefore, schools should also pay attention to training students' refereeing ability in the training of students. With the enhancement of people's aesthetic ability, the degree of sports competitions is increasingly fiercer, and presents a variety of forms, thereby proposing higher requirements for the ability to act according to circumstances and the professional ability of referees. In the teaching process, the evaluation of teachers and schools or companies on the refereeing ability of students is higher than students' evaluation on themselves. Therefore, it is said that the sports training major plays an important role in training students' refereeing ability. At present, the refereeing ability training in specialized schools is mainly reflected in special training, theoretical training and practical training, and finally, attention is paid to training students' refereeing ability in various activities.

As can be seen through analysis on relevant abilities of graduates, graduates from sports training major having received prolonged education unexpectedly have a downward trend in the aspect of refereeing ability. Factors leading to the result are mainly that students fail to have relevant professional training and theoretical course content in the process of learning, have a little practical arrangement, and improve their refereeing ability in additional referee training. Moreover, students experience more things in the process of self-growth, so that they more objectively evaluate themselves, thus having slightly decreased subjective consciousness in self-evaluation. However, anyway, the refereeing ability is an important content of professional ability test for graduates from sports training major.

Sports training includes the initial state, training plan, objective, evaluation and the like of athletes. Guiding and organization ability is the most important in sports training, and specialized sports training can strengthen training of students' guiding and organization ability. The contents contained in guiding and organizing specialized training mainly include: accurately explaining technical specifications, accurately demonstrating technical actions, etc., enabling students or learners to master learning essentials; proficiently mastering training skills and characteristics, and guiding practice; accurately and promptly correcting practitioners' errors; and proposing reasonable teaching activities complying with the practice for trainees of different ages.

The ability to guide and organize professional training is affected by various factors, including technical level, language ability, management ability and the like. Moreover, the employers' evaluations are usually between the schools' evaluations and the students' evaluations, and the schools' satisfaction degree about students can only reach $70 \%$. Therefore, it is necessary to make overall arrangement in students' learning specialized courses, theory and social practice, and thus it is necessary to strengthen reasonable arrangement of school curricula.

\section{Countermeasures for professional talent training of sports training major in comprehensive colleges and universities}

Majors and curricula in any school must be set by presetting reasonable training objective schemes. Comprehensive colleges and universities shall also preset perfect training schemes in talent training, pay attention to student training in many aspects, especially training in cognitive ability and exercise skills, in the light of the current situation of their own education and actual situation of their own students, and shall not neglect training students' moral quality and comprehensive ability. Training objectives play an important role in student learning in years of campus life. Different from specialized sports colleges and universities, comprehensive colleges and universities also need to pay attention to training professional talents in other fields whilst training talents majoring in sports training, and are therefore at a disadvantage in the overall competitiveness. Therefore, it is necessary to plan the training objectives in more detail, formulate systematic training objectives, and attach great importance to training students' comprehensive ability. Compared with specialized sports schools, comprehensive colleges and universities have great advantages on the basic knowledge, shall strive for improvement on the premise of having 
weakness in other aspects, cannot relax efforts to keep existing advantages on the basic knowledge, and shall generally enhance the comprehensive ability of students.

Courses should be set independently by schools in accordance with the relevant national policies. Therefore, if comprehensive colleges and universities blindly follow the general trend and follow the pattern of traditional sports colleges and universities during course setting, it will be more difficult for them to get rid of the situation that they are at a disadvantage. Students' comprehensive level can be further improved by innovative course setting based on their own existing advantages on theoretical knowledge, highlighting key points and differences of course setting, and enabling students to more effectively and comprehensively receive professional knowledge. In the process of teaching, attention shall also be paid to the teaching quality. Furthermore, especially, the problem of sports training major cannot be neglected. Comprehensive colleges and universities must attach importance to sports training, so that students trained by them can occupy a place in sports competitions. Therefore, it is also necessary to attach importance to the course teaching process in usual course setting, the implementation and learning degree of which directly affect the competitiveness of comprehensive colleges and universities in this aspect.

The combination of theory with practice is the best learning way, and the most effective means for students to improve themselves. At present, institutions of higher learning greatly lack internship opportunities except the internship requirements when approaching graduation, so that students only learn theoretical knowledge except the practical courses arranged by their schools. The practical courses of schools are significantly different from specific social practices, so comprehensive colleges and universities must attach strengthened importance to practice. Training of sports training talents involves training of a variety of abilities and a variety of contents. Therefore, internship experience of students can also be enriched by different forms of practices in internship, and comprehensive colleges and universities can improve students' comprehensive business level by diversified internship methods, which is also the most effective way to enhance students' specialization level. In addition, schools can cooperate with relevant enterprises by using their social resources or other reciprocal means, and can not only increase the exercise opportunities of students but also provide enterprises with labor force support, when necessary, by way of providing interns, thereby enhancing specialized learning opportunities.

\section{Conclusion}

Sports training plays an important role in improving students' professional level. Therefore, comprehensive colleges and universities must pay attention to attaching strengthened importance to the sports training major. Only by establishing perfect relevant contents of sports training, can professional talent training be better promoted, so as to provide more professional talents for the development of sports undertakings in China, better promote the development of sports training major in comprehensive colleges and universities, and improve their comprehensive competitiveness.

\section{Acknowledgment}

Subject No: National Social Science Fund Educational Education Youth Project + "up-anddown", the first line of urban high school sports development and countermeasures research + CLA 130196

\section{References}

[1] Xiong Yi \& Wang Xiang. Analysis on Status Quo of Cultivation and Reform of Sports Training Professionals [J]. Bulletin of Sport Science \& Technology, 2009, 8 (8): 19.

[2] Zhao Yanli. On the Present Situation and Countermeasures of the Teaching Plan of Undergraduates of Sports Training Major in National Colleges and Universities [D]. Suzhou: Suzhou University, 2007. 
[3] Meng Fansheng, Xiang Xianlin, Wang Yubing, et al. Sports Training Specialized Course Offered and Cultivation of Compound-Applied-Type Talent [J]. Journal of Shanghai University of Sport, 2007, (11): 57-61.

[4] Zhou Ming, Chen Min, et al. Discussion on the Training Mode of Undergraduate Talents of Sports Training Major in Colleges and Universities of China [J]. Journal of Guangzhou Sport University, 2004, 24 (5): 81-83. 